\title{
In vitro free radical scavenging and antidiabetic activity of aqueous and ethanolic leaf extracts: a comparative evaluation of Argyreia pierreana and Matelea denticulata
}

\author{
Venkataiah Gudise ${ }^{1 *}$ (D) Bimalendu Chowdhury ${ }^{2}$ and Arehalli S. Manjappa ${ }^{3}$
}

\begin{abstract}
Background: Oxidation is believed to play a vital role in the pathogenesis of diabetes mellitus by lipid peroxidation; DNA and protein damage leads to the development of vascular complications like coronary heart disease, stroke, neuropathy, retinopathy, and nephropathy. The herbal preparations are complementary and alternative medicines to allopathic drugs which are believed to cause adverse events. Therefore, the current study was aimed to identify the novel plants, which belong to the genera Argyreia (Argyreia pierreana (AP)) and Matelea (Matelea denticulata (MD)), and assess the aqueous and ethanolic leaf extracts for in vitro antioxidant and antidiabetic potential by DPPH, OH* superoxide, and glucose uptake and gene expression (GLUT-4 and PPARY) studies using the L-6 cell line respectively.

Results: The preliminary scrutiny revealed the presence of polyphenols, flavonoids, terpenoids, steroids, tannins, alkaloids, and glycosides. The total phenolic and flavonoid contents of ethanolic extracts were found higher than those of aqueous extracts. The ethanolic extracts exhibited the superior antioxidant capacity when compared with aqueous extracts. However, the ethanolic extract of MD was shown superlative glucose uptake activity (72.54\%) over control (0.037\%) and GLUT-4 and PPARY gene expressions (1.17 and 1.20) in term of folds respectively over cell control (1.00).

Conclusion: The ethanolic leaf extracts of both plants showed significant in vitro antioxidant and antidiabetic activities compare to aqueous extracts. The Matelea denticulata ethanolic leaf extract exhibited superior activity. This superior activity might be due to their higher phenolic and flavonoid content. However, further approaches are needed to define these activities.
\end{abstract}

Keywords: Argyreia pierreana, Matelea denticulata, Antiradical activity, Antidiabetic activity, GLUT-4 and PPARY expression study

\section{Background}

Traditional herbal medicines have shaped the basis of human health care, and further research will improve global health $[1,2]$. Presently, about $80 \%$ of the world population (according to WHO) uses herbal drugs for some aspects of primary health care. Globally, the use of medicinal plants predates antibiotics and other

\footnotetext{
* Correspondence: venkatpharma22@gmail.com

${ }^{1}$ Department of Pharmacology, SSJ College of Pharmacy, Vattinagulapally,

Gandipet, Hyderabad, Telangana State 500075, India

Full list of author information is available at the end of the article
}

contemporary drugs $[3,4]$. In addition, many culinary herbs and spices were tested for their biological activities in Alzheimer's disease management and other chronic diseases $[5,6]$.

The natural antioxidant defence mechanism, in all human and other aerobic organisms, prevents the oxidative damage. Since the natural antioxidant defence mechanism is inadequate on its own, the nutritional consumption of antioxidants is suggested $[7,8]$. Currently, synthetic antioxidants are replaced by natural antioxidants as the former are reported to have carcinogenic properties. Plants are the 
primary source of natural antioxidant molecules capable of eliminating or neutralizing the harmful reactive oxygen species (ROS) [9]. The natural antioxidants are also free-radical scavengers, reduction agents, pro-oxidant metal complexes, singlet oxygen quenchers, etc. They can also safeguard the human body from free radicals and delay the progression of many chronic illnesses (such as cancer, heart disease, and stroke) and boost the plasma's antioxidant ability and prevent lipid oxidative rancidity in foods $[10,11]$.

The incidence of diabetes mellitus (DM) is very high all over the world. Natural antidiabetic drugs are now becoming increasingly popular due to severe financial burdens and side effects connected with allopathic therapy strategies [12-14]. The herbal preparations are complementary and alternative medicine (CAM) and the search for the discovery of novel compounds derived from natural sources like herbs or plant is growing mainly due to acquired resistance, side effects, and adverse events (AE) of allopathic medication [15-18]. In search of new medicinal plants that pose concurrent antioxidant and antidiabetic activity, we have screened the leaf extracts of two novel plants belonging to the genera Argyreia (Argyreia pierreana) and Matelea (Matelea denticulata).

Argyreia pierreana (AP), a new flowering plant, which belongs to the family Convolvulaceae, genus Argyreia, is found throughout India and China. In India, it is commonly found in Assam, West Bengal, Bihar, Orissa, and South India. There are several supporting pharmacological activities that have been proven for various species or genus of Argyreia belongs to family Convolvulaceae [19-21].

Matelea denticulata (MD) belongs to family Apocynaceae, genus Matelea. Matelea is a genus of flowering plants and contains about 200 species, which are commonly known as milkvine. It is found in Bell, Burnet, Palo Pinto, and Parker counties; Brown, Comanche, Eastland, and Johnson counties; and India [22, 23].

Previous studies of Argyreia and Matelea genus plant extracts indicated the presence of flavonoids, phenols, tannins, and saponins which are the supporting compounds with various pharmacological activities. These plants are novel belonging to the same genus which might have the new kind of phytochemicals for the concurrent diseases. Hence, we selected these plants with the aim and objective to find the supportive phytochemicals for in vitro antioxidant and antidiabetic activity and comparison of their potency to determine the superlative plant extract for discovering the potential phytoformulation. Further, our study extended to develop the plant-derived chemicals for concomitant metabolic disorders by applying suitable bioavailability-enhancing techniques.

\section{Methods}

\section{Collection of plant material}

The Argyreia pierreana and Matelea denticulata used in this study were collected and authenticated by Dr. Madhava Chetty, Department of Botany, S.V. University, Tirupathi, India (A voucher test number of 1364 and 1596).

\section{Preparation of the extracts}

The leaves were collected, cleaned, and shade dried for 1 week. The aqueous extract was prepared by maceration $(50 \mathrm{~g} / 500 \mathrm{~mL})$ at room temperature for $72 \mathrm{~h}$. The ethanolic (90\%) extract was prepared using the Soxhlet mechanical assembly at $60-75{ }^{\circ} \mathrm{C}$ for $48 \mathrm{~h}$. The ethanolic extricate was sifted, dried under reduced temperature at $40{ }^{\circ} \mathrm{C}$ in a hot air oven and stored below $20{ }^{\circ} \mathrm{C}$ until further use $[24,25]$.

\section{Characterization of prepared extract Determination of preliminary phytochemicals}

The bioactive components of the extracts (aqueous and ethanolic extracts of both plants) were identified using standard qualitative phytochemical tests [26].

\section{Estimation of total phenol content}

$0.2 \mathrm{~mL}$ (from $10 \mu \mathrm{g} / \mathrm{mL}$ stock) of test substance and standard were blended with Folin-Ciacalteau reagent $(1 \mathrm{~mL})$. Then, sodium carbonate $(0.8 \mathrm{~mL}$ of $10 \% \mathrm{w} / \mathrm{w})$ was added and incubated (Biovision, India) for $60 \mathrm{~min}$ at $27^{\circ} \mathrm{C}$. A total of $100 \mu \mathrm{L}$ of the above reaction mixture was transferred to a microplate (Gilson, USA) and absorbance was measured at $750 \mathrm{~nm}$ using an ELISA plate reader (Biotech, USA). The total phenol content of the test sample was expressed as gallic acid (monohydrate) in $\mathrm{mg} / \mathrm{gm}$ of the extract using the calibration curve of gallic acid $(20 \mu \mathrm{g} / \mathrm{mL}$ to $200 \mu \mathrm{g} / \mathrm{mL})$ [27].

\section{Estimation of total flavonoid content}

The test substance $(0.2 \mathrm{~mL}$ of $10 \mu \mathrm{g} / \mathrm{mL}$ stock $)$ and standard were blended with demineralized water $(1.8$ $\mathrm{mL}$ ). Then, $0.5 \mathrm{~mL}$ of this solution was mixed with $95 \%$ ethanol $(1.5 \mathrm{~mL}), 1 \mathrm{M}$ potassium acetate $(0.1 \mathrm{~mL})$, $0.1 \mathrm{~mL}$ of aluminium chloride hexahydrate $\left(\mathrm{AlCl}_{3}\right)$, and deionized water $(2.8 \mathrm{ml})$ and incubated (Biovision, India) for $40 \mathrm{~min}$ at $27^{\circ} \mathrm{C}$. The above solution $(100 \mu \mathrm{L})$ was placed into a microplate (Tarsons, India) and the absorbance was measured at $415 \mathrm{~nm}$ using an ELISA plate reader (Biotech, USA). The total flavonoid content of the test sample was compared with quercetin as standard (mg/gram) of the extract using the calibration curve (20 to $200 \mu \mathrm{g} / \mathrm{mL}$ ) [27]. 


\section{Scavenging activity by DPPH assay}

The assay was carried out in a 96-well microtitre plate (Tarsons, India). Briefly, the methanolic solution of DPPH $(200 \mu \mathrm{L})$ was added to wells previously containing $10 \mu \mathrm{L}$ of aqueous and ethanolic extracts separately. The wells containing extracts $(10 \mu \mathrm{L})$ and methanol $(200 \mu \mathrm{L})$ were considered as test blank. The wells containing methanolic DPPH $(200 \mu \mathrm{L})$ and DMSO $(10 \mu \mathrm{L})$, and wells containing plain methanol $(200 \mu \mathrm{L})$ and DMSO $(10 \mu \mathrm{L})$ were considered as control and control blank, respectively. The plate was then incubated for $30 \mathrm{~min}$ at $37^{\circ} \mathrm{C}$ and then the absorbance was measured at $490 \mathrm{~nm}$ using an ELISA plate reader (Biotech, USA) [28-30].

$\%$ of scavenging activity $=[($ Optical density of control -Optical density of sample)/OD control] x 100

\section{Hydroxyl $\left(\mathrm{OH}^{\circ}\right)$ radical scavenging activity}

In Eppendorf tubes (10 mL capacity), EDTA $(0.1 \mathrm{~mL}$ of $1 \mathrm{mM}), \mathrm{FeCl}_{3}(0.01 \mathrm{~mL}$ of $10 \mathrm{mM}), \mathrm{H}_{2} \mathrm{O}_{2}(0.1 \mathrm{~mL}$ of $30 \%)$, deoxyribose $(0.36 \mathrm{~mL}$ of $10 \mathrm{mM})$, test or standard substance $(1 \mathrm{~mL})$ of various concentrations, phosphate buffer saline (0.33 mL, pH 7.4), and ascorbic acid solution $(0.1 \mathrm{~mL}$ of $0.1 \mathrm{mM})$ were taken and incubated (Biovision, India) at $37^{\circ} \mathrm{C}$ for $1 \mathrm{~h}$. Distilled water was used as a test blank and control blank instead of a reagent mixture. Post incubation, $0.5 \mathrm{~mL}$ of the response blend containing $\mathrm{OH}^{*}$ radical is pipetted out and TCA and TBA reagents $(0.5 \mathrm{~mL})$ was added to all tubes except control blank. The vials were kept in a boiling water bath for $20 \mathrm{~min}$ and cooled to room temperature and the supernatant $(0.2 \mathrm{~mL})$ was transferred to the microtitre plate. The absorbance was measured at $532 \mathrm{~nm}$ using an ELISA plate reader (Biotech, USA) [30]. The \% of $\mathrm{OH}^{*}$ radical scavenging activity was determined, as was the DPPH assay.

\section{Superoxide radical scavenging activity}

Briefly, freshly prepared alkaline DMSO $(1 \mathrm{~mL}$ of $5 \mathrm{mM}$ $\mathrm{NaOH}$ in DMSO), test and standard substances $(0.3 \mathrm{~mL}$ prepared in distilled DMSO) of various concentrations, and Nitro Blue Tetrazolium (NBT, $0.1 \mathrm{~mL}$ of $1 \mathrm{mg} / \mathrm{mL}$ stock) were mixed to get a final volume of $1.4 \mathrm{~mL}$. 0.1 $\mathrm{mL}$ of distilled water was used in place of NBT for test blank and control blank. $0.1 \mathrm{~mL}$ of the blend was then transferred to the microtitre plate and the absorbance was measured at $560 \mathrm{~nm}$ using an ELISA microplate reader (Biotech, USA) [30]. The \% of superoxide radical scavenging activity was determined, as was the DPPH assay.

\section{Reducing power assay}

Briefly, $2 \mathrm{~mL}$ of phosphate buffer $(0.2 \mathrm{M}, \mathrm{pH} 6.6)$ and potassium ferric cyanide ( $2.5 \mathrm{~mL}$ of $1 \%$ stock) were added to test or standard samples $(0.5 \mathrm{~mL})$. The distilled water, instead of potassium ferric cyanide, was added to test blank and control blank. Then, the reaction mixture was heated at $50{ }^{\circ} \mathrm{C}$ for $30 \mathrm{~min}$. The resulting mixture was cooled to room temperature, mixed with $2.5 \mathrm{~mL}$ $(10 \%)$ of trichloroacetic acid, and then centrifuged for 10 min at $3000 \mathrm{rpm}$. The supernatant $(5 \mathrm{~mL})$ was then mixed with condensed water $(5 \mathrm{~mL})$ and ferric chloride ( $1 \mathrm{~mL}$ of $0.1 \%$ stock) and incubated at room temperature for $10 \mathrm{~min}$. The blend $(0.1 \mathrm{~mL})$ was then placed into a microtitre plate and the absorbance was measured at $700 \mathrm{~nm}$ using an ELISA plate reader (Biotech, USA). The obtained findings were presented in terms of ascorbic acid equivalent/g of extract. The increase in reducing power is indicated by an increase in absorbance [31].

\section{Total antioxidant capacity}

Briefly, the test solution $(0.1 \mathrm{~mL}$, prepared in DMSO) containing a reducing species was mixed with a reagent solution $(1 \mathrm{~mL}$, a mixture of $0.6 \mathrm{M}$ sulphuric acid, $4 \mathrm{mM}$ ammonium molybdate and $28 \mathrm{mM}$ sodium phosphate) and heated at $95{ }^{\circ} \mathrm{C}$ for $90 \mathrm{~min}$. Then, the samples were cooled to room temperature and $0.1 \mathrm{~mL}$ was transferred to the microtitre plate. The absorbance was measured at $695 \mathrm{~nm}$ using an ELISA plate reader (Biotech, USA). The obtained values were expressed as $\mathrm{mM}$ equivalent of ascorbic acid [30].

\section{In vitro antidiabetic activity by glucose uptake method}

The effect of extracts on glucose uptake was examined using differentiated rat skeletal muscle cells (L-6 cells). The cell cultures (70-80\% confluence) were allowed, for 4-6 days, to differentiate in Dulbecco's modified eagle growth medium (DMEM) comprising $2 \%$ FBS. Then, the differentiated cells were serum-starved overnight, washed once with HEPES buffered Krebs Ringer Phosphate solution (KRP buffer), and incubated at $37{ }^{\circ} \mathrm{C}$ for $30 \mathrm{~min}$ in KRP buffer containing $0.1 \%$ BSA. The cells were further incubated with test and standard drugs (non-toxic concentrations) and negative controls for $30 \mathrm{~min}$ at $37{ }^{\circ} \mathrm{C}$. The D-glucose solution $(1 \mathrm{M}, 20 \mu \mathrm{L})$ was added at the same time to all wells before incubation. Post incubation, the supernatant solutions were aspired from wells and the cells were washed three times using the KRP buffer solution (ice-cold). Aliquots of cell lysates (prepared in $0.1 \mathrm{M}$ $\mathrm{NaOH}$ solution) were analysed for cell-associated glucose using a glucose assay kit (ERBA) [32, 33].

In vitro gene expression study on GLUT-4 and PPAR-gamma The effect of test substances on GLUT-4 and PPAR $\gamma$ gene expressions of L- 6 cells was determined with respect to untreated cells [34, 35]. 
RNA isolation and cDNA synthesis Post-treatment with the test substances, the L-6 cells were lysed using Tri-extract reagent and the prepared cell lysates were treated chloroform to isolate the RNA. The upper layer (amongst three distinct layers observed), in a fresh tube, was mixed with isopropanol (an equal volume) and incubated at $-20{ }^{\circ} \mathrm{C}$ for $10 \mathrm{~min}$. The samples were then centrifuged and the pellet was resuspended in an appropriate volume of ethanol. Ethanol was then evaporated, the pellet was air-dried, and the appropriate volume of TAE buffer was added. The isolated total RNA was further used for cDNA synthesis.

The cDNA was synthesized by priming with oligo dT primers followed by reverse transcriptase enzyme treatment according to the manufacturer's protocol (Thermo scientific). The cDNA thus synthesized was subjected to PCR (polymerase chain reaction) for the amplification of collagen, elastin, and glyceraldehyde 3-phosphate dehydrogenase (GAPDH, internal control gene).

RT-PCR procedure The mRNA expression levels of GLUT-4 and PPAR $\gamma$ were determined using semiquantitative RT-PCR (reverse transcriptase-polymerase chain reaction). GLUT-4 and PPAR $\gamma$ cDNAs (in $50 \mu \mathrm{L}$ of the reaction mixture) were amplified using specifically designed primers (Eurofins, India), and GAPDH (Housekeeping gene) was co-amplified with each reaction. The amplification conditions and primers used in the present study are in accordance with the earlier research paper [36].

\section{Statistical analysis}

The obtained findings were presented as mean \pm standard deviation (SD). The findings were analysed by GraphPad Prism (8.01) using nonlinear regression for in vitro antioxidant activity and ANOVA (analysis of variance) for glucose uptake activity. The differences were considered statistically significant when $p<0.05$.

\section{Results}

\section{Preliminary phytochemical screening}

The prepared AEAP, EEAP, AEMD, and EEMD were screened for the presence of various phytochemicals such as polyphenols, flavonoids, terpenoids, steroids, saponins, tannins, alkaloids, and glycosides. The steroids were found absent in aqueous extracts of both plants (AEAP and AEMD) whereas the glycosides were found absent in ethanolic extracts of both plants (EEAP and EEMD) (Table 1). These results clearly revealed the solubility pattern of the above-screened phytoconstituents.

Total phenol and flavonoid content of the extracts The total phenol and flavonoid concentrations of the plant extracts are presented in Table 2. All plant extracts
Table 1 The phytochemical profile of the prepared plant leaf extracts

\begin{tabular}{lllllllll}
\hline Extracts & P & F & T & St & S & Ta & Al & Gl \\
\hline AEAP & + & + & + & - & + & + & + & + \\
EEAP & + & + & + & + & + & + & + & - \\
AEMD & + & + & + & - & + & + & + & + \\
EEMD & + & + & + & + & + & + & + & - \\
\hline
\end{tabular}

The sign (+) indicates the presence and (-) indicates absence of phytochemicals: $P$ polyphenols, $F$ flavonoids, $T$ terpenoids, $S t$ steroids, $S$ saponins, Ta tannins, Al alkaloids; Gl glycosides

(AEAP, EEAP, AEMD, and EEMD) showed a considerably elevated amount of phenolic compounds over flavonoids. Further, the ethanolic extracts showed a substantially increased concentration of phenolic compounds than aqueous extracts (AEAP and AEMD). In addition, the results revealed no significant difference in total flavonoid compounds amongst aqueous and alcoholic extracts.

\section{Free radical scavenging activity}

The prepared extracts were screened for their antiradical activity against various free radicals $\left(\mathrm{DPPH}, \mathrm{OH}^{\circ}\right.$, and superoxide radicals). The scavenging activity of all prepared extracts, against all free radicals tested, is found to be concentration-dependent (Fig. $1 \mathrm{a}-\mathrm{c}$ ). The $\mathrm{IC}_{50}$ values obtained with the tested extracts are presented in Table 3.

In the DPPH assay, both ethanolic extracts (EEAP and EEMD) showed significantly higher scavenging activity over aqueous extracts (AEAP and AEMD) at a tested amount of $1000 \mu \mathrm{g} / \mathrm{mL}$ (Fig. 1a and Additional file 1: Table S1). Amongst the ethanolic extracts, the EEMD displayed significantly higher scavenging activity than EEAP indicating superior anti-oxidant activity of the Matelea denticulata plant leaf. The $\mathrm{IC}_{50}$ value for EEMD is found to be $827.3 \mu \mathrm{g} / \mathrm{mL}$ over other extracts (more than $1000 \mu \mathrm{g} / \mathrm{mL}$ ). However, the ascorbic acid (test standard) displayed significantly higher antioxidant activity $\left(\mathrm{IC}_{50} 88.4 \mu \mathrm{g} / \mathrm{mL}\right.$ ) over all extracts tested.

In the $\mathrm{OH}^{*}$ radical scavenging assay, all the extracts inhibited the $\mathrm{OH}^{*}$ free radicals. We observed a dosedependent quenching of hydroxyl free radicals for all extracts. The scavenging activity of ethanolic extracts

Table 2 Total phenolic and flavonoid content of the prepared plant leaf extracts

\begin{tabular}{lll}
\hline Extracts & TPC & TFC \\
\hline AEAP & $109.37 \pm 0.002$ & $37.507 \pm 0.008$ \\
EAAP & $130.49 \pm 0.009$ & $44.485 \pm 0.004$ \\
AEMD & $92.70 \pm 0.079$ & $41.532 \pm 0.002$ \\
EEMD & $148.78 \pm 0.252$ & $46.510 \pm 0.002$ \\
\hline
\end{tabular}

Values presented are mean \pm SD. TPC total phenolic content expressed as gallic acid $(\mathrm{mg} / \mathrm{gm})$ of the extracts, TFC total flavonoid content expressed as quercetin $(\mathrm{mg} / \mathrm{gm})$ of the extracts 


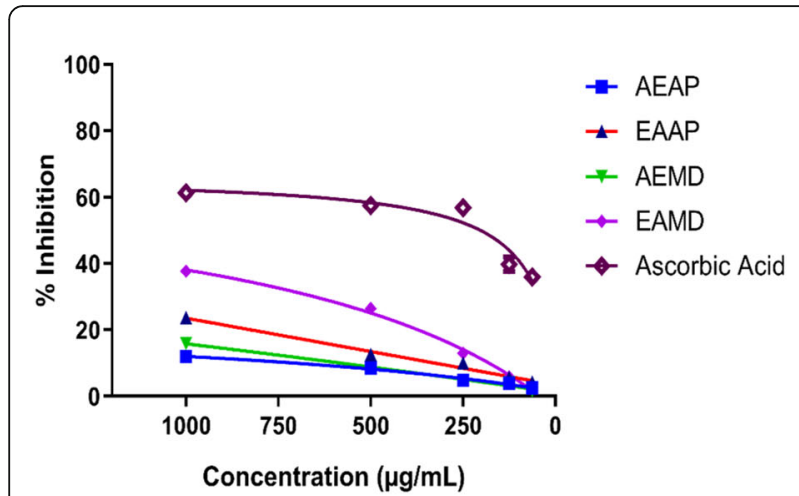

A

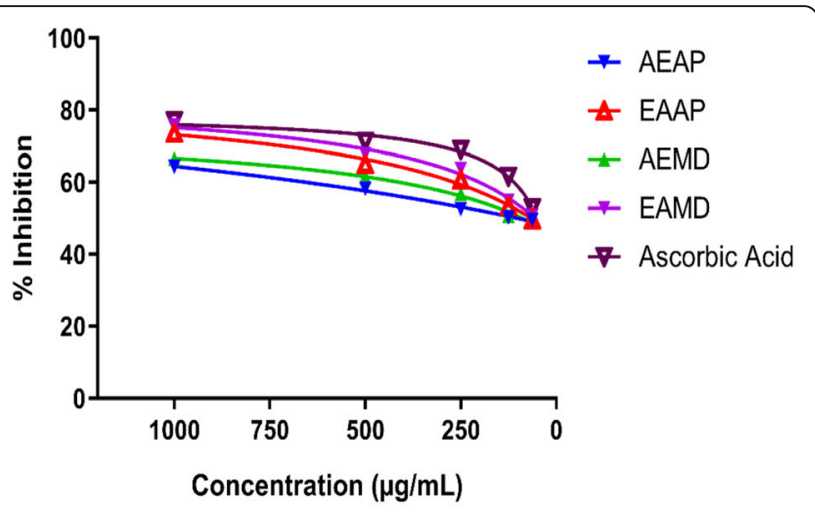

B

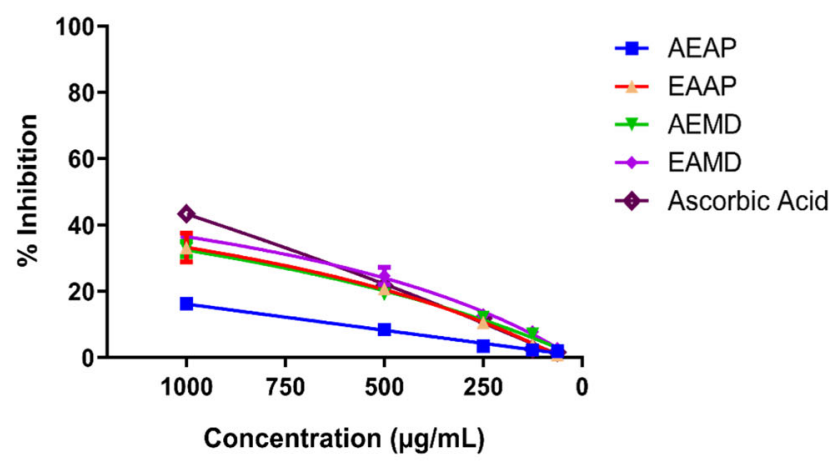

C

Fig. 1 Free radical scavenging activity of extracts: a Scavenging activity by DPPH assay. $\mathbf{b}$ Hydroxyl radical scavenging activity. c Superoxide radical scavenging activity. The values are presented as mean $\pm \mathrm{SD},(n=3)$

(EEAP and EEMD), as compared with their aqueous extracts, are found similar to standard ascorbic acid at the tested amount of $1000 \mu \mathrm{g} / \mathrm{mL}$ (Fig. 1b and Additional file 1: Table S2). Both EEAP and EEMD showed scavenging activity that is comparable with standard ascorbic acid against hydroxyl free radicals as compared with DPPH free radicals. Further, EEAP showed scavenging

Table $3 I_{50}$ Free radical scavenging activity of prepared plant leaf extracts

\begin{tabular}{llll}
\hline Test substance & \multicolumn{3}{l}{$\mathrm{I} \mathrm{C}_{50}(\mu \mathrm{g} / \mathrm{mL})$} \\
\cline { 2 - 4 } & \multicolumn{2}{l}{ Radical scavenging assay } & \multicolumn{2}{l}{ Superoxide } \\
\cline { 2 - 4 } & \multicolumn{1}{l}{ DPPH } & $\mathrm{OH}^{\circ}$ & $>1000$ \\
\hline AEAP & $>1000$ & $459.90 \pm 0.65$ & $>1000$ \\
EEAP & $>1000$ & $425.30 \pm 0.51$ & $>1000$ \\
AEMD & $>1000$ & $300.10 \pm 0.60$ & $942 \pm 0.89$ \\
EEMD & $827.30 \pm 0.43$ & $68.97 \pm 0.77$ & $>1000$ \\
AA & $88.40 \pm 0.84$ &
\end{tabular}

Values presented are mean $\pm S D,(n=3) . A A$ ascorbic acid activity comparable with EEMD against hydroxyl free radicals than DPPH free radical.

Similarly, the superoxide free radical assay revealed the scavenging activity of EEAP, EEMD, and AEMD which is comparable with standard ascorbic acid whereas AEAP displayed significantly less scavenging activity over other tested extracts and standard (Fig. 1c and Additional file 1: Table S3). Surprisingly, the aqueous extract of Matelea denticulata plant leaf also displayed scavenging activity comparable with ethanolic extracts and standard ascorbic acid against superoxide free radicals than DPPH and $\mathrm{OH}^{*}$ free radicals. Overall, the EEMD displayed scavenging activity that is significantly higher than other extracts tested and comparable with standard ascorbic acid.

\section{Reducing power activity}

The reducing power activity of the tested extracts and standard ascorbic acid is presented in Fig. 2. All extracts displayed concentration-dependent reducing activity. 


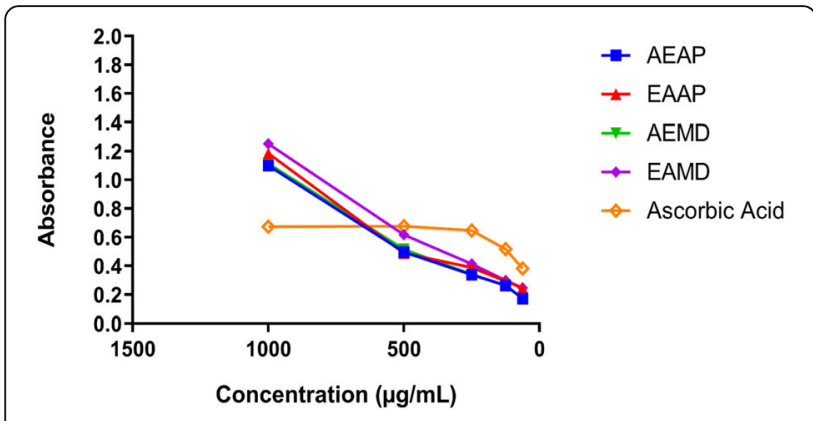

Fig. 2 Reducing power activity of the extracts. The values are presented as mean \pm SD, $(n=3)$

The increase in the extract amount results in increased reducing activity. All extracts showed significantly high reducing activity over standard ascorbic acid at a tested amount of $1000 \mu \mathrm{g} / \mathrm{mL}$. However, the reducing activity of ascorbic acid was found higher than all extracts at lower concentrations (up to $250 \mu \mathrm{g} / \mathrm{mL}$ ). Amongst extracts tested, the EEMD showed high reducing activity over other extracts tested.

\section{Total antioxidant capacity}

The total antioxidant activity of all tested extracts is presented in Fig. 3. The ethanolic extracts of AP and MD displayed the superior antioxidant capacity (107.80 \pm 0.08 and $214.10 \pm 10.03)$ when compared with aqueous extracts AP and MD $(34.74 \pm 1.04$ and $52.83 \pm 1.98) \mathrm{mg}$ equivalent. ascorbic acid/g extract respectively. Amongst both ethanolic plant extracts, the EEMD showed significantly higher antioxidant capacity. These findings clearly revealed the superior antioxidant activity of the plant Matelea denticulata (leaf) as compared with Argyreia pierreana (leaf).

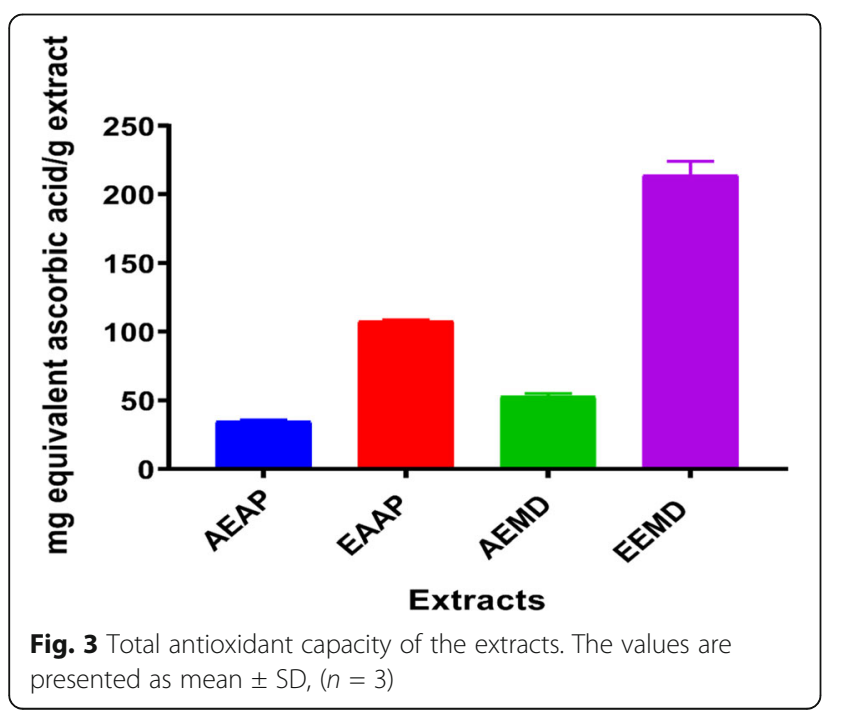

In vitro antidiabetic activity by glucose uptake method In vitro, glucose uptake by L-6 cells was measured to determine the effect of extracts on cellular glucose uptake behaviour. Further, the antidiabetic activity of the extracts was compared with standard marketed antidiabetic drugs (Insulin and Metformin) (Table 4) and (Fig. 4). Insulin $(1 \mathrm{IU} / \mathrm{mL})$ and Metformin $(100 \mu \mathrm{g} / \mathrm{mL})$ treatments caused significantly increased glucose uptake (about 120\% and $92 \%$ respectively) over the untreated control group. The treatment of L- 6 cells with ethanolic extracts caused significantly higher glucose uptake as compared with aqueous extracts. Amongst ethanolic extracts, the EEMD caused about 2.26-fold higher glucose uptake as compared with EEAP. When compared with the standard drug (Insulin, $1 \mathrm{IU} / \mathrm{mL})$ the EEMD $(200 \mu \mathrm{g} / \mathrm{mL})$ caused significantly less (about 47\%) glucose uptake. Further, the glucose uptake caused by EEMD was found about 22\% less than the standard metformin $(100 \mu \mathrm{g} / \mathrm{mL})$. Although EEMD caused significantly less L-6 glucose uptake as compared with standard drugs at the tested amount of $200 \mu \mathrm{g} / \mathrm{mL}$ the EEMD could cause L-6 glucose uptake comparable with standard drugs at higher concentrations. However, further studies are needed to validate this fact.

\section{In vitro gene expression study on GLUT-4 and PPAR- gamma}

The effect of EEAP and EEMD treatments GLUT-4 and PPAR $\gamma$ mRNA expressions in L-6 cells is determined using a semi-quantitative RT-PCR technique (Fig. 5). The scanning densitometric analysis was performed to determine the GLUT-4 and PPARY mRNA expressions of the untreated and Pioglitazone, EEAP and EEMD treated L-6 cells. The results revealed the elevated level of GLUT-4 expression in treated cells as compared with control cells. The Pioglitazone (standard drug), EEMD and EEAP treatments resulted in about 1.22, 1.17 and 1 fold increased GLUT-4 transcription levels when compared with untreated cells (Fig. 6a and Additional file 1: Table S4).

Table 4 In vitro glucose uptake activity by L-6 myotubes in the presence of plant leaf extracts

\begin{tabular}{ll}
\hline Test sample & \% glucose uptake over control \\
\hline Control & $0.037 \pm 0.037$ \\
Insulin $(1 \mathrm{IU} / \mathrm{mL})$ & $119.40 \pm 4.807^{* * *}$ \\
Metformin $(100 \mu \mathrm{g} / \mathrm{mL})$ & $91.99 \pm 1.863^{* * *}$ \\
$\operatorname{AEAP}(200 \mu \mathrm{g} / \mathrm{mL})$ & $16.98 \pm 1.039^{* * *}$ \\
$\operatorname{EEAP}(200 \mu \mathrm{g} / \mathrm{mL})$ & $32.11 \pm 2.639^{* * *}$ \\
AEMD $(200 \mu \mathrm{g} / \mathrm{mL})$ & $30.4 \pm 1.405^{* * *}$ \\
EEMD $(200 \mu \mathrm{g} / \mathrm{ml})$ & $72.54 \pm 1.383^{* * *}$
\end{tabular}

Values presented are mean $\pm \mathrm{SD},(n=3) .{ }^{*} p<0.05,{ }^{* *} p<0.01,{ }^{* * *} p<0.001$ over control 


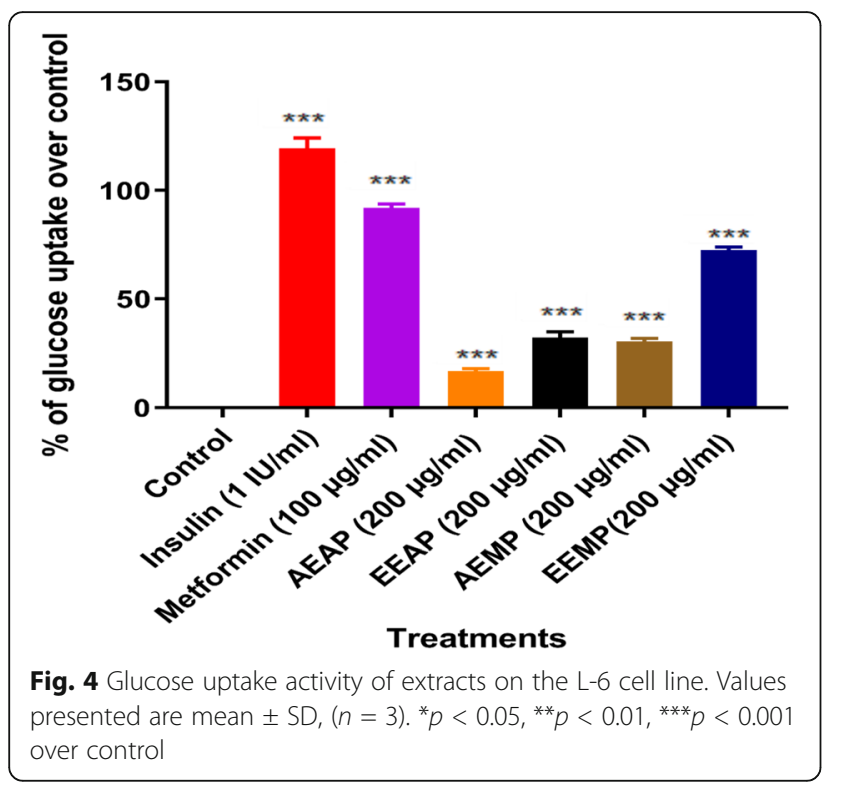

Additionally, the PPARy expression of untreated and pioglitazone-, EEAP-, and EEMD-treated L-6 cells was determined. Surprisingly, the EEMD treatment $(200 \mu \mathrm{g} /$ $\mathrm{mL}$ ) showed about a 1.2-fold increase in PPARY expression when compared with untreated cells (Fig. 6b and Additional file 1: Table S4). Besides, the PPARY expression of EEMD treated cells was found comparable with standard pioglitazone treated cells. Similarly, the EEAP treatment showed elevated (about 1.07 fold) PPARY expression when compared with untreated cells. The L-6 cells treatment with further increased concentration of EEMD and EEAP may result in further increased

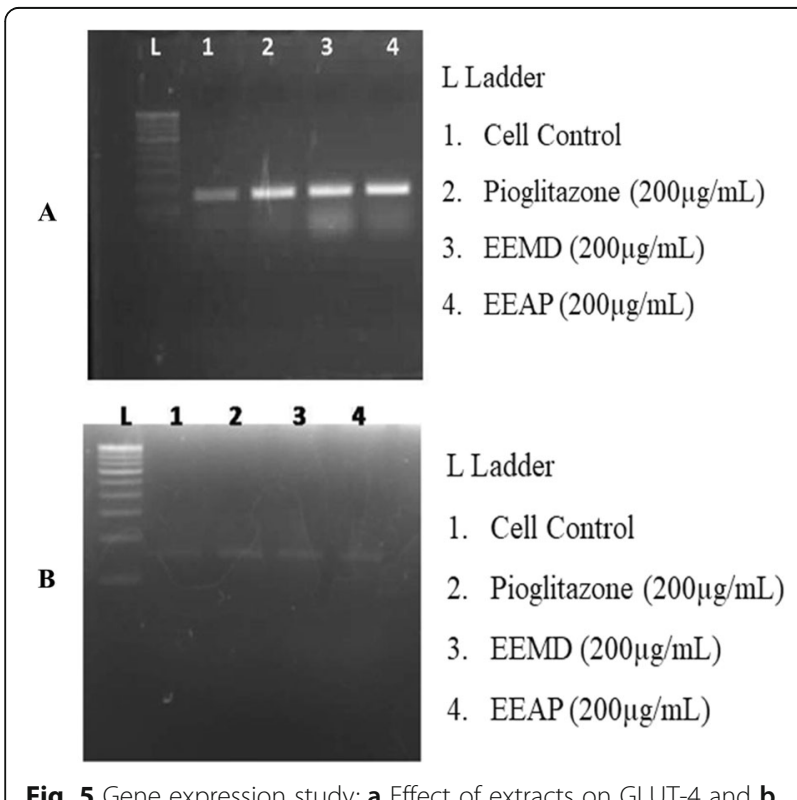

Fig. 5 Gene expression study: a Effect of extracts on GLUT-4 and b PPARy transcripts in L6 myotubes determined by RT-PCR technique
GLUT-4 and PPARy expressions. To ascertain these facts, however, further studies are needed. The above findings indicate the correlation between increased cellular glucose uptake and elevated GLUT4 and PPARy gene expression.

\section{Discussion}

In recent years, the hunt for antioxidant phytoconstituents has been significantly increased due to their potential therapeutic application in diverse chronic and infectious diseases. In search of new plants, in the current research, we have screened the in vitro antioxidant and antidiabetic activities of aqueous and ethanolic leaf extracts of two plants which belong to the genera Argyreia (AP) and Matelea (MD).

The free radicals (associated with one or more unpaired electrons) are highly unstable and attain stability by extracting electrons of other molecules. Further, the free radicals, due to their highly reactive nature, damage the transient chemical species. The increased risk of many chronic diseases in humans was associated with the elevated free radical level as a result of a failure in endogenous antioxidant defence mechanism or exposure to environmental oxidants or damage to cell structures [37]. Therefore, we can avoid chronic disease progression and risks associated with them by supplementing the patients with proven antioxidants or by increasing the antioxidant defence.

The role of medicinal plants in decreasing free radicalcaused tissue injury reveals their antioxidant activity [10]. The current research, therefore, explores the antioxidant activity of leaves aqueous and ethanolic extracts of plants $\mathrm{AP}$ and MD. As free radicals are different chemical entities, the extracts were investigated against many free radicals in order to prove their antioxidant activity via various mechanisms (such as free radical scavenging, reducing activity, potential complexing of pro-oxidant metals, and quenching of singlet oxygen) [38, 39].

The antioxidant characteristics of the extracts are first assessed on the basis of their capacity to trap free radical $\mathrm{DPPH}$. By their capacity to donate hydrogen, the antioxidants decrease and decolorate the DPPH. The experimental findings revealed that the ethanolic extracts, as compared with aqueous extracts, have significantly high DPPH free radical scavenging activity. The leaves of the plant MD showed superior DPPH free radical scavenging activity than the leaves of the plant AP.

The $\mathrm{OH}^{*}$ radical formation in the liver or other ironrich tissues through Fenton reaction contributes to the lipid peroxidation initiation. Besides, the $\mathrm{OH}^{*}$ radicals cause DNA mutagenesis and various proteins inactivation (owing to their high reactivity) $[29,40]$ are found involved in the initiation of inflammation and cancer and are extremely harmful to the tissues [41]. Therefore, 


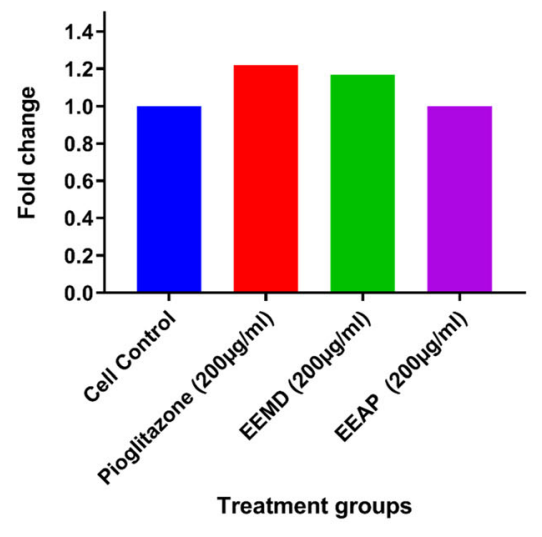

A

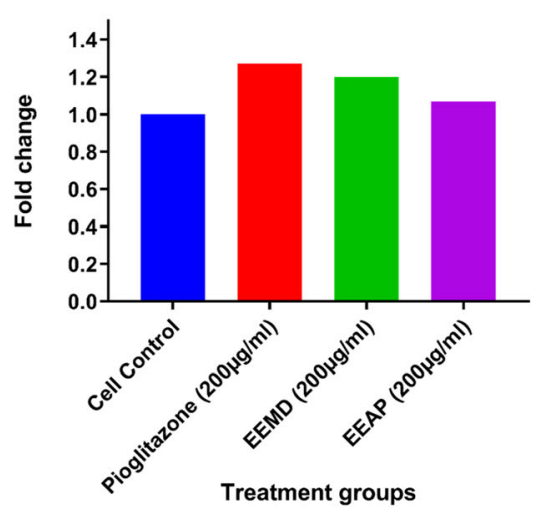

B

Fig. 6 Densitometric analysis of gene transcripts: a The relative level of GLUT-4 and b PPARY gene expression is normalized to GAPDH. Values shown depict arbitrary units

the $\mathrm{OH}^{*}$ radical scavenging activity can be considered as one of the best indicators of a compound's antioxidant potential. In the current study, the obtained results revealed that the EEAP and EEMD have significantly high $\mathrm{OH}^{*}$ radical scavenging activity which is found similar to ascorbic acid.

Superoxide radical is very harmful to cellular components (as a precursor of more reactive species) [30] and can result in in vivo $\mathrm{H}_{2} \mathrm{O}_{2}$ formation through a dismutation reaction. The formed $\mathrm{H}_{2} \mathrm{O}_{2}$ (not very reactive itself) further produces $\mathrm{OH}^{*}$ radicals in the cells which eventually causes cell damage. Therefore, the removal of $\mathrm{H}_{2} \mathrm{O}_{2}$ from the cell system is imperative for the antioxidant defence system. The obtained experimental data revealed the comparable antioxidant activity of EEAP, EEMD, and AEMD with standard ascorbic acid. The AEAP displayed significantly less antioxidant activity over other tested substances and standards. Overall, the EEMD displayed significantly high free radical scavenging activity than other extracts tested, and is comparable with ascorbic acid.

The alkaloids, tannins, glycosides, flavonoids, and polyphenols are found in the extracts. Many researchers have shown that most of these compounds (polyphenols and flavonoids) have antioxidant properties [42]. Further, the polyphenols (ortho-hydroxyl phenolic compounds like quercetin, gallic acid, caffeic acid, and catechin) prevents the $\mathrm{H}_{2} \mathrm{O}_{2}$ caused by mammalian cell damage $[43,44]$. In the current research, the observed superior free radical scavenging activities of ethanolic leaf extracts of plants AP and MD could be correlated to their high flavonoid and phenolic compounds. Moreover, the antiradical activity relies on the availability and capacity of these extracts to provide hydrogen or electron atom [10]. In the present research, the findings acquired indicate the free radical stabilizing ability of extracts by giving them electron or hydrogen.
Extracts are composed of a number of scavenging compounds which may act synergetically to enhance the antiradical activity in a variety of oxidative stress and in diseases like diabetes [44]. The difference in antiradical activity observed amongst the extracts in the present study, it may be due to the presence of different level of several bioactive compounds (such as phenols and flavonoids) which have the ability to donate hydrogen atoms to stabilize the free radicals $[43,44]$.

The reducing power of compounds would serve as an indicator of their antioxidant potential. Thus, in the current research, we assessed the reducing power of the extracts by measuring their capacity to reduce $\mathrm{Fe}^{3+}$ to $\mathrm{Fe}^{2+}$ by donating electron [45]. All extracts showed the highest reduction capacity (optical density) as compared with ascorbic acid at a tested amount of $1000 \mu \mathrm{g} / \mathrm{mL}$. This capacity of the extracts to reduce $\mathrm{Fe}^{3+}$ could be ascribed to the presence of reduction agents, such as polyphenols, and the number and/or the position of the hydroxyl groups on polyphenols [45].

In addition, in the current research, the total antioxidant activity of the extracts is assessed and compared with the standard ascorbic acid. The obtained results revealed the superior antioxidant activity of the ethanolic extracts as compared with aqueous extracts. Further, the EEMD displayed a significantly higher antioxidant activity than EEAP. Many researchers have reported a strong relationship between the antioxidant activity of many plant species and their total phenol content [46, 47]. These results further validate the potential antioxidant nature of polyphenols. Thus, in the present study, the obtained higher antioxidant activity of the extracts could be correlated to their high amount of polyphenols which functions as reduction agents, hydrogen donors, free radical scavenger, singlet oxygen quenchers, and metal chelators [48]. However, further comprehensive studies 
are required to isolate the antioxidant components of these extracts and determine their in vivo biological activities.

The skeletal muscle is the main part of the human body responsible for postprandial glucose use and its function is essential for maintaining normal levels of blood glucose [49]. The non-insulin-dependent diabetes mellitus (NIDDM) is characterized by a defect in insulin-stimulated skeletal muscle glucose uptake [50]. In this context, in the current research, the effect of extracts on skeletal muscle cell (L-6) glucose utilization is determined in vitro. All aqueous and ethanolic extracts have significantly enhanced glucose uptake when compared with the control group. The glucose utilization by L-6 cells is found significantly high in the presence of EEMD than all other extracts. Further, the EEMD effect on glucose utilization is found almost comparable with standard metformin. This increased glucose utilization in the presence of extracts could be correlated to their effect on a number of L-6 cell glucose transporters or other receptors that are involved in the glucose transport across the cell membrane.

In the current research, an additional effort is taken to define the mechanism behind enhanced glucose utilization by L- 6 cells in the presence of extracts. The GLUT- 4 is the main transporter of glucose present in insulin-responsive tissues (skeletal muscle and adipose tissue) [51], and the abnormal glucose transport in insulin-resistant type 2 diabetes is linked with poor GLUT-4 translocation (from the intracellular membrane storage site to the plasma membrane) and/or defective insulin signaling cascade. The significant increase in GLUT-4, P13 kinase, and mRNA expressions, in the presence of insulin, in euglycemic and hyperinsulinemic clamp further validates the function of GLUT-4 and P13 kinase in the insulin-mediated transfer of glucose. Along with insulin, the PPARy agonists (such as rosiglitazone and pioglitazone) have also been reported to facilitate the transport of glucose in type 2 diabetes by acting as insulin sensitizers [52].

In the present study, the effect of extracts on L-6 cell GLUT-4 and PPARy expressions is determined to validate their role in glucose uptake. The obtained results revealed the elevated expressions of GLUT- 4 and PPAR $\gamma$ in L-6 cells treated with all extracts as compared with untreated L- 6 cells. The EEMD treatment caused increased L- 6 cellular GLUT-4 and PPAR $\gamma$ expressions as compared with other extracts. Thus, its effect on increased glucose uptake by L-6 cells is might be due to its ability to elevate GLUT-4 and PPAR $\gamma$ expressions. In addition, these results are consistent with the literature reports which revealed the increased glucose uptake as a result of enhanced GLUT-4 and PPAR $\gamma$ levels in L-6 cells $[35,51,52]$. The obtained results in the current research are in accord to support the glucose uptake- enhancing property of EEMD. Based on gene expression study results, we can conclude that the EEMD would trigger glucose transport through the up-regulation of GLUT-4 and PPAR $\gamma$ expressions. However, additional research is required to reveal the other mechanisms or molecules which resulted in increased glucose transport in the presence of EEMD.

The promising in vitro antioxidant and antidiabetic activity of these plant extracts might be due to the presence of supportive phytochemicals such as polyphenols, flavonoids, terpenoids, and tannins. Additionally, the individual component identification and biological activities are underway.

\section{Conclusion}

The preliminary phytochemical analysis indicated that, the newly identified plant's leaf extracts contain supportive phytochemicals such as flavonoids, polyphenols, steroids, and terpenoids. The study results revealed that the ethanolic extracts of both plants' leaf extracts showed significant in vitro antioxidant and antidiabetic activity when compared with aqueous extracts. The ethanolic leaf extract of Matelea denticulata exhibited superior in vitro free radical scavenging and antidiabetic activity amongst the other extracts. This superior activity might be due to their high phenolic and flavonoid content than the leaves of Argyreia pierreana. Besides, other parts of this plant or whole plant would show similar or superior antioxidant and antidiabetic activities than the leaf. However, further research is needed to determine the study-specific phytochemicals with the mechanisms behind these activities.

\section{Supplementary information}

Supplementary information accompanies this paper at https://doi.org/10 1186/s43094-019-0014-9.

Additional file 1: Table S1. Scavenging activity of the plants extracts by DPPH assay. Table $\mathbf{S 2 .} \mathrm{OH}^{*}$ radical scavenging activity of the extracts. Table S3. Superoxide radical scavenging activity of the extracts. Table S4.The gene expression level of different genes normalized to GAPDH

\section{Abbreviations}

AEAP: Aqueous extract of Argyreia pierreana; AEMD: Aqueous extract of Matelea denticulata; ANOVA: Analysis of variance; AP: Argyreia pierreana; BSA: Bovine serum albumin; CDNA: Complementary DNA; DM: Diabetes mellitus; DMEM: Dulbecco's modified eagle growth medium; DMSO: Dimethylsulfoxide; DPPH: 2,2-diphenyl-1-picrylhydrazyl; EEAP: Ethanolic extract of Argyreia pierreana; EEMD: Ethanolic extract of Matelea denticulata; ELISA: Enzyme-linked immunosorbent assay; FBS: Fetal bovine serum; GADPH: Glyceraldehyde 3-phosphate dehydrogenase; GLUT4: Glucose transporter-4; $\mathrm{H}_{2} \mathrm{O}_{2}$ : Hydrogen peroxide; HEPES: (4-(2-

hydroxyethyl)-1-piperazineethanesulfonic acid); KRP: Krebs ringer phosphate solution; L-6: Rat skeletal muscle cells; MD: Matelea denticulata;

$\mathrm{NaOH}$ : Sodium hydroxide; NBT: Nitro blue tetrazolium; OD: Optical density; $\mathrm{OH} \bullet$ : Hydroxyl radical; PPARy: Peroxisome proliferator-activated receptor gamma; RNA: Ribonucleic acid; RT-PCR: Reverse transcription polymerase chain reaction; TAE: Tris-acetate-EDTA; TPC: Total phenol content;

WHO: World health organization 


\section{Acknowledgements}

We are very much grateful to Dr. Viral, Radiant Research Services Pvt. Ltd Bangalore, for providing research facilities and helping to carry out this research work.

\section{Authors' contributions}

VG performed all the above research activities. BC conceived the study and participated in its design and coordination. AM participated in the sequence alignment and drafted the manuscript. All authors have read and approved the manuscript.

\section{Funding}

This research did not received any specific grant from funding agencies in the public, commercial, or not-for-profit sectors.

\section{Availability of data and materials}

The data used to analyse the findings of this study are available from the corresponding author upon request.

\section{Ethics approval and consent to participate}

Not applicable.

\section{Consent for publication}

Not applicable.

\section{Competing interests}

The authors declare that they have no competing interests.

\section{Author details}

'Department of Pharmacology, SSJ College of Pharmacy, Vattinagulapally, Gandipet, Hyderabad, Telangana State 500075, India. ${ }^{2}$ Department of Pharmacology, Roland Institute of Pharmaceutical Sciences, Khodasingi, Berhampur, Odisha 760010, India. ${ }^{3}$ Department of Pharmaceutics, Tatyasaheb Kore College of Pharmacy, Warananagar, Kodoli, Maharashtra 416113, India.

\section{Received: 29 June 2019 Accepted: 15 November 2019}

\section{Published online: 19 December 2019}

\section{References}

1. Tilburt JC, Kaptchuk TJ (2008) Herbal medicine research and global health: an ethical analysis. Bull World Health Organization 86(8):594-599

2. Bodeker C, Bodeker G, Ong C.K, Grundy C.K, Burford G, Shein K (2005) WHO global atlas of traditional, complementary and alternative medicine, Geneva, Switzerland.

3. Bordeker G (2002) Medicinal plants-towards sustainability and securityA paper prepared for IDRC medicinal plants global network. IDRC, South Asia Regional Office, New Delhi, India

4. Aslam MS, Ahmad MS (2016) Worldwide importance of medicinal plants: Current and historical perspectives. Recent Adv Biol Med 88(2):88-93

5. Akram M, Nawaz A (2017) Effects of medicinal plants on Alzheimer's disease and memory deficits. Neural Regen Res 12(4):660-670

6. Jivad N, Rabiei Z (2014) A review study on medicinal plants used in the treatment of learning and memory impairments. Asian Pac J Trop Biomed 10(4):780-789

7. Kumar RS, Rajkapoor B, Perumal P (2012) Antioxidant activities of Indigofera cassioides Rottl. Ex. DC. using various in vitro assay models. Asian. Pac J Trop Biomed 2(4):256-261

8. Venkatachalam U, Muthukrishnan S (2012) Free radical scavenging activity of ethanolic extract of Desmodium gangeticum. J Acute Med 2(2):36-42

9. Carocho M, Ferreira IC (2013) A review on antioxidants, prooxidants and related controversy: Natural and synthetic compounds, screening and analysis methodologies and future perspectives. Food Chem Toxicol 51:15-25

10. Sylvie DD, Anatole PC, Cabral BP, Veronique PB (2014) Comparison of in vitro antioxidant properties of extracts from three plants used for medical purpose in Cameroon: Acalypharacemosa, Garcinia lucida and Hymenocardia lyrate. Asian Pac J Trop Biomed 4(2):S625-S632

11. Cai Y, Luo Q, Sun M, Corke H (2004) Antioxidant activity and phenolic compounds of 112 traditional Chinese medicinal plants associated with anticancer. Life Sci 74(17):2157-2184
12. Akinmoladun AC, Obuotor EM, Farombi EO (2010) Evaluation of antioxidant and free radical scavenging capacities of some Nigerian indigenous medicinal plants. J Med Food 13(2):444-451

13. Tangvarasittichai S (2015) Oxidative stress, insulin resistance, dyslipidemia and type 2 diabetes mellitus. World J. Diabetes 6(3):456-480

14. Al-Goblan AS, Al-Alfi MA, Khan MZ (2014) Mechanism linking diabetes mellitus and obesity. Diabetes Metab Syndr Obes 7:587-591

15. Prabakaran K, Shanmugavel G (2017) Antidiabetic activity and phytochemical constituents of Syzygiumcumini seeds in puducherry region, South India. Int J Pharmacognosy Phytochem Res 9(7):985-989

16. Asgar MA (2013) Anti-diabetic potential of phenolic compounds. Intl J Food Prop 16(1):91-103

17. Sarian MN, Ahmed QU, Mat Soad SZ, Alhassan AM, Murugesu S, Perumal V (2017) Antioxidant and antidiabetic effects of flavonoids: A structure-activity relationship based study. BioMed Res Int 2017:1-14

18. Aba PE, Asuzu IU (2018) Mechanism of actions of some bioactive antidiabetic activity principles from phytochemicals of medicinal plants. Indian J Nat Prod Resour 9(2):85-96

19. Staples GW, Traiperm P, Chow J (2015) Another new Thai Argyreia species (Convolvulaceae). Phytotaxa 204(3):223-229

20. Bois MDGJ (1906) Argyreia pierreana Bois. Revue Horticole 78:560

21. Fang RC, Staples G (1995) Convolvulaceae. Flora China 16:271-325

22. Roxburgh L, Choisy M (1995) Argyreia. Flora of China16:313-321.

23. McDonnell A (2014) Non-twining milkweed vines of oklahoma: an overview of Matelea biflora and Matelea cynanchoides (apocynaceae). Oklahoma Native Plant Record 14:67-79

24. Harborne JB (1998) Phytochemical Methods: A guide to modern techniques of plant analysis, 3rd edn. Springer; Germany; ISBN 0412572605, 9780412572609

25. Kameswara Rao B, Renuka Sudarshan P, Rajasekhar MD, Nagaraju N, Appa Rao C (2003) Antidiabetic activity of Terminalia pallida fruit in alloxan induced diabetic rats. J. Ethnopharmacol 85(1):169-172

26. Khandewal KR (2000) Practical Pharmacognosy Technique and experiments. 9th edn. Nirali Publications Pune 149-156.

27. Jin-Yuarn L, Ching-Yin T (2007) Determination of total phenolic and flavonoid contents in selected fruits and vegetables, as well as their stimulatory effects on mouse splenocyte proliferation. Food Chemistry 101:140-147

28. Badami S, Gupta MK, Suresh B (2003) Antioxidant activity of the ethanolic extract of Striga orobanchioides. Journal of Ethnopharmacology 85:227-230

29. Wonyoung $\mathrm{K}$, Heekyoung $\mathrm{Y}$, Hyun $\mathrm{JH}$, Chang HH, Young JL (2012) Antioxidant activities of kiwi fruit extract on carbon tetrachloride-induced liver injury in mice. Korean J Vet Res 52(4):270-280

30. Jaishree V, Shrishailappa B, Suresh B (2008) In vitro antioxidant activity of Enicostemma axillare J. Health Science 54(5):524-528

31. Narasimharaju K, Nagarasanakote VT, Nagepally Venkataramareddy J, Ramaiah N, Sathyanarayana S, Bharat K (2015) Antifungal and antioxidant activities of organic and aqueous extracts of Annona squamosa Linn. leaves. J Food Drug Analysis 23:798-802

32. Francis D, Rita L (1986) Rapid colorometric assay for cell growth and survival modifications to the tetrazolium dye procedure giving improved sensitivity and reliability. J Immunol Methods 89(2):271-277

33. Takigawa-Imamura H, Sekine T, Murata M, Takayama K, Nakazawa K, Nakagawa J (2003) Stimulation of glucose uptake in muscle cells by prolonged treatment with scriptide: a histone deacetylase inhibitor. Biosci Biotechnol Biochem 67(7):1499-1506

34. Koivisto UM, Martinez-Valdez H, Bilan PJ, Burdett E, Ramlal T, Klip A (1991) Differential regulation of the GLUT1 and GLUT4 glucose transport systems by glucose and insulin in L6 muscle cells in culture. J Biol Chem 266(4): 2615-2621

35. Isakoff SJ, Taha C, Rose E, Marcuslon J, Klip A, Skolnik EY (1995) The inability of phosphatidylinositol 3-kinase activation to stimulate GLUT4 translocation indicates additional signaling pathways are required for insulin-stimulated glucose uptake. Proc Natl Acad Sci USA 92(22):10247-10251

36. Neumann C, Yu A, Welge-Lüssen U, Lütjen-Drecoll E, Birke M (2008) The effect of TGF-beta2 on elastin, type VI collagen, and components of the proteolytic degradation system in human optic nerve astrocytes. Invest Ophthalmol Vis. Sci 49(4):1464-1472

37. Lobo V, Pati A, Phatak A, Chandra N (2010) Free radicals, antioxidants and functional foods: Impact on human health. Pharmacogn Rev 4(8):118-126

38. Kunwar A, Priyadarsini Kl (2011) Free radicals, oxidative stress and importance of antioxidants in human health. J Med Allied Sci 1(2):53-60 
39. Kasote DM, Katyare SS, Hegde MV, Bae H (2015) Significance of antioxidant potential of plants and its relevance to therapeutic applications. Int J Biol Sci 11(8):982-991

40. Karuna DS, Dey P, Das S, Kundu A, Bhakta T (2017) In vitro antioxidant activities of root extract of Asparagus racemosus Linn. J. Tradit Complement. Med 8(1):60-65

41. Pinto E, Sigaud-kutner T, Leitao MA, Okamoto OK, Morse D, Colepicolo P (2003) Heavy metal-induced oxidative stress in algae. J Phycol 39(6):1008-1018

42. Zhang YJ, Gan RY, Li S, Zhou Y, Li AN, Xu DP (2015) Antioxidant phytochemicals for the prevention and treatment of chronic diseases. Molecules 20(12):21138-21156

43. Pandey KB, Rizvi SI (2009) Plant polyphenols as dietary antioxidants in human health and disease. Oxid Med Cell Longev 2(5):270-278

44. Mathew A, Abraham TE, Zakaria ZA (2015) Reactivity of phenolic compounds towards free radicals under in vitro conditions. J Food Sc Technol 52:5790-5798

45. Ravishankar M, Juliet Esther VC (2018) In vitro antioxidant activity of Hydrophila auriculata leaves extract and silver nanoparticles. J Nanosci Tech 4(5):549-551

46. De Oliveira AMF, Sousa Pinheiro L, Souto Pereira CK, Neves Matias W, Albuquerque Gomes R, Souza Chaves O (2012) Total phenolic content and antioxidant activity of some malvaceae family species. Antioxidants 1(1):33-43

47. Piluzza G, Bullitta S (2011) Correlations between phenolic content and antioxidant properties in twenty-four plant species of traditional ethnoveterinary use in the Mediterranean area. Pharm Biol 49(3):240-247

48. Liang T, Yue W, Li Q (2010) Comparison of the phenolic content and antioxidant activities of Apocynum venetum L. (Luo-Bu-Ma) and two of its alternative species. Int J Mol Sci 11(11):4452-4464

49. Gupta RN, Pareek A, Suthar M, Rathore GS, Basniwal PK, Jain D (2009) Study of glucose uptake activity of Helicteres isora Linn. fruits in L-6 cell lines. Int. J. Diabetes Dev. Ctries 29(4):170-173

50. Rajeswari R, Sriidevi M (2014) Study of in vitro glucose uptake activity of isolated compounds from hydro alcoholic leaf extract of Cardiospermum Halicacabum Linn. Int J Pharm Pharm Sci 6(11):181-185

51. Zhao P, Ming Q, Qiu J, Tian D, Liu J, Shen J (2018) Ethanolic extract of Folium Sennae mediates the glucose uptake of L6 cells by GLUT4 and $\mathrm{Ca}^{2+}$. Molecules 23(11):E2934

52. Kumar PM, Venkataranganna MV, Manjunath K, Viswanatha GL, Ashok A (2014) Methanolic extract of Momordica cymbalaria enhances glucose uptake in L6 myotubes in vitro by up-regulating PPAR-y and GLUT-4. Chin J Nat Med 12(12):895-900

\section{Publisher's Note}

Springer Nature remains neutral with regard to jurisdictional claims in published maps and institutional affiliations.

\section{Submit your manuscript to a SpringerOpen ${ }^{\circ}$ journal and benefit from:}

- Convenient online submission

- Rigorous peer review

- Open access: articles freely available online

- High visibility within the field

- Retaining the copyright to your article

Submit your next manuscript at $\boldsymbol{\nabla}$ springeropen.com 